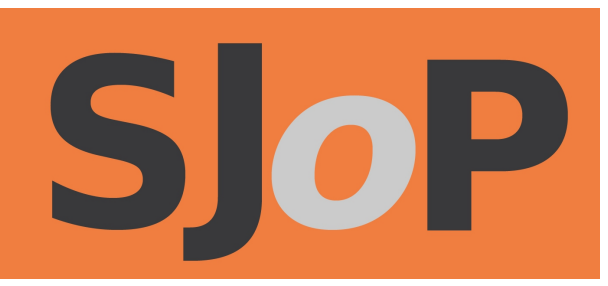

Book review: The actor and the camera, by Denis Lawson

MARK STEVENSON

The Scottish Journal of Performance

Volume 2, Issue 1; December 2014

ISSN: 2054-1953 (Print) / ISSN: 2054-1961 (Online)

Publication details: http://www.scottishjournalofperformance.org

To cite this article: Stevenson, M., 2014. Book review: The actor and the camera, by Denis Lawson. Scottish Journal of Performance, 2(1): pp.135138.

To link to this article: $\underline{h t t p: / / d x . d o i . o r g / 10.14439 / s j o p .2014 .0201 .12 ~}$

(C) This work is licensed under a Creative Commons
Attribution 4.0 International License. See
http://creativecommons.org/licenses/by/4.0/ for details. 


\title{
Book review: The actor and the camera, by Denis Lawson
}

\author{
MARK STEVENSON
}

DOI: 10.14439/sjop.2014.0201.12

Publication date: 16 December 2014

The actor and the camera, by Denis Lawson. London: Nick Hern Books, 2014; ISBN 9781848423459 (£10.99)

The actor and the camera is a guidebook for inexperienced actors looking to work in film and television. Denis Lawson is sharing his approach garnered from 40 years in the business. Trained, as I was, at the Royal Scottish Academy of Music and Drama (now known as the Royal Conservatoire of Scotland), Lawson is keen to pass on the gems of his knowledge learned on the job rather than at drama school. As I now teach at the RCS, I am constantly looking for ways to explore the process of acting and explain to our students the differences in approach and requirements of theatre and screen. This work is a useful addition to the arsenal of books on screen acting already published.

Lawson is not interested in theory, but in practice. This is not a book on how to act, but assumes the reader has the basic (theatrical) skills and gives advice on how to convert these to the surprisingly different media of film and TV. Based on a lifetime's work as an actor for theatre, TV and film, as well as some experience behind the camera as a director, he seems ideally placed to provide these insights and tips.

Generally speaking the text follows the actor on their journey through the process of making a film or television 
series-getting the part, preparing the script, what to expect on set, post-production responsibilities and so on. It is casually divided with subheadings at thumb-level making it relatively easy to navigate. There are occasional, but useful diversions from this chronological approach into, for example, the technology of the cameras worked with and modern technologies such as performance-capture.

Lawson's book is readable with an informal, personal style. It is an insider's view-no-nonsense, honest and revealing. For me, it had three main messages: the collaborative nature of filming; knowledge of the technicality of the process; and perhaps the most novel, the actor's relationship to the camera.

On collaboration, Lawson talks us through all the important personnel and relationships we need to cultivate in the filming process, establishing the actor's role within the larger whole.

$\mathrm{He}$ covers the technicality of shooting with clear explanations and tips, sometimes illustrated, to help demystify what may be an arcane process to many. For Lawson, knowledge is power: if you understand how something works, you have more creative control over your own craft.

While these first two areas have been extensively covered in other works (for example, Michael Caine's well-known Acting in Film or Mel Churcher's Acting for Film) it is this third aspect-relationship to camera-that provides the most important lesson for me. Lawson's (clearly successful) attitude is that his performance is 'a very private relationship between me and the lens'. He talks of the image you are creating on film or within the camera as the endgoal of your work. This is a seachange from theatre-based 
practice, where relationship between actors, or actors and audience, is key, and is therefore a very useful concept for actors-in-training to understand in accommodating their style.

I believe actors inexperienced in camera work could benefit from this book. As Lawson suggests, while drama schools do usually now offer some form of on-camera training, the main thrust of drama-training in the UK is still theatrebased, despite the fact that most graduating drama students are more likely to be employed televisually than theatrically. Having the right skills for the different media of acting can only enhance employability.

As Lawson writes in his introduction, while an actor still has to make their own mistakes and learn their own lessons, he offers this book as a springboard to hopefully 'help you arrive at your filmic destination a few years earlier than you might have done' (p.ix).

It may have been useful to offer some exercises, like other works do on DVD (even at a similar price), or examples of Lawson's approach to text work, but this is not the stated aim of the book. He achieves what he sets out to do: give actors a clear understanding of the practicalities of filming and their place in it. The actor and the camera is an easily accessible and stimulating read offering insight, food for thought, and giving enough information to hopefully empower inexperienced actors to have confidence in building a working relationship with the camera. 


\section{References}

Caine, M., 1989. Acting in film: an actor's take on movie making. London: Applause.

Churcher, M., 2011. Acting for film. London: Random House.

\section{About the review author}

MARK STEVENSON gained a BA in Human Sciences from Oxford University before re-training as an actor at the Royal Scottish Academy of Music and Drama. He worked for a number of years as an actor both in Scotland and further afield before returning to Scotland to teach. He currently teaches acting and theatre history at the Royal Conservatoire of Scotland. He directs projects both within and without the Conservatoire. With his RCS colleague Katya Kamotskaia he has translated several plays and this year conducted research into the application of Butkevich's method of improvisation to rehearsal. Their most recent collaboration, based on this research, has recently won the 'Grand Prix' at the 34th International Student Festival at VGIK in Moscow. 